\title{
BROWNFIELD REGENERATION FROM THE PERSPECTIVE OF RESIDENTS: PLACE CIRCUMSTANCES VERSUS CHARACTER OF RESPONDENTS
}

\author{
Stanislav MARTINÁT ${ }^{\mathrm{a}}$, Josef NAVRÁTIL ${ }^{\mathrm{b}}$, Kamil PÍCHA ${ }^{\mathrm{c}}$, Kamila \\ TUREČKOVÁa ${ }^{\mathrm{a}}$ Petr KLUSÁČEK ${ }^{\mathrm{d}}$
}

\author{
${ }^{a}$ Silesian University in Opava, School of Business Administration in Karvina, Univerzitní nám. 1934, \\ Karviná CZ-73340 email: martinat@opf.slu.cz \\ ${ }^{\mathrm{b}}$ University of South Bohemia, Faculty of Agriculture, Studentská 1668, České Budějovice CZ-37005 \\ email: josefnav@gmail.com \\ ${ }^{\mathrm{c}}$ University of South Bohemia, Faculty of Economics, Studentská 13, České Budějovice CZ-37005 email: \\ kpicha@ef.jcu.cz \\ d Institute of Geonics of the Czech Academy of Sciences, Department of Environmental Geography, \\ Drobného 28, Brno CZ-60200 email: klusacek@geonika.cz
}

Cite this article: Martinát, S., Navrátil, J., Pícha, K., Turečková, K., Klusáček, P. (2017). Brownfield regeneration from the perspective of residents: Place circumstances versus character of respondents. Deturope, 9, 2: $71-92$

\begin{abstract}
Little attention is paid to the inhabitants' views of places where brownfields are localized. If the residents attract some attention in this matter, it is most often at global level, and no influence of responders' characteristics or of place of questioning on the perception of problems of brownfields is examined in more detail. However, there is a consensus among researchers that these variables have an immediate effect on perception. That is why we set the objective to assess the impact of inhabitants' characteristics and of the place of residence on the structure of preferences for various types of brownfields regeneration. Respondents were questioned in three zones (city center, vicinity of the city and the peripheral surroundings of the city) of two cities (497 respondents in Karviná and 833 respondents in České Budějovice, both Czech Republic). Socio-economic characteristics of the respondents were pursued and respondents commented on the extent of agreement with the use of existing brownfields in three defined zones of cities. The impact of origin of the resident (geographic characteristics) and of the character of the respondent (soci-economic characteristics) on a structure in preferences was studied sequentially by means of three methods of multidimensional data analysis (PCA, RDA, and Variation Partitioning). All methods led us to reveal a structure of four factors of preferences for regeneration: green/sport, housing/shopping, industry, and entertainment. Following the RDA the statistically significant variables to influence the structure of answers are both geographical variables - city, zone of a city - and three socio-economic variables - gender, age, and education. Preference for commercial-residential use of brownfields has a distinctive centre-periphery distribution within the city. The preferences of the revitalization through the reactivation of the industry are given primarily by the particular city, and the impact of both types of variables (characteristics of the respondent and the place of questioning) is significant, however the shared explainable variation is negligible (geographic variables explain 51.6\% and characteristics of respondents $46.6 \%$ ).
\end{abstract}

Keywords: brownfields, regeneration, perception, residents, Central Europe 


\section{INTRODUCTION}

The issue of brownfields (as unused, abandoned, or neglected buildings or sites that were utilized previously) has recently been widely discussed (Burinskiene, Bielinskas, Podviezko, Gurskiene, \& Maliene, 2017; Jigoria-Oprea \& Popa, 2017; Longo \& Campbell, 2017). Intensive discussion has taken place in many fields (Doick, Sellers, Castan-Broto, \& Silverthorne, 2009; Simis, Awang, \& Arifin, 2016; van Duijn, Rouwendal, \& Boersema, 2016).

Thus, after years of debates, the question of brownfields formation and re-use is still an open issue (Nekolova, Hajek, \& Novosak, 2016). Attitudes of stakeholders are still under study (Alexandrescu, Martinat, Klusacek, \& Bartke, 2014), too. It is no surprise, that special attention is paid to the opinions and attitudes of enterprises, and of state and local administration representatives (Alexandrescu, Rizzo, Pizzol, Critto, \& Marcomini, 2016; H. R. Kim \& Jang, 2017; Pizzol et al., 2016; Rizzo et al., 2015). Likewise, the satisfaction of visitors with the regenerated brownfields was studied (Berki, 2017; Franz, Gueles, \& Prey, 2008). Quite unexpected should be the fact, that a relatively low attention is paid to the opinions of the citizens, in the residence of which the brownfields are located. The importance of support of the local populations is pointed out to be a vital factor of success of any development (Lusticky \& Musil, 2016).

For the above mentioned reasons, we have opt for the assessment of the impact of the citizens' characteristics and the impact of location on the structure of preferences for the particular type of brownfield regeneration to be the objective of this paper.

\section{CONCEPTUAL BACKGROUND}

As already mentioned above, studies dealing with the residents' opinion on regeneration of brownfields are quite rare in literature (Table 1). We can divide them into the two basic types:

- study of perception of brownfields regeneration by means of visual methods,

- study of perception of existing brownfields and residents' preferences for the revitalization of the brownfields.

Second type of studies decidedly predominates. 
Table 1 Review of literature dealing with of residents' opinions

\begin{tabular}{|c|c|c|c|c|c|}
\hline authors & dependent & independent & $\begin{array}{l}\text { number of } \\
\text { respondents }\end{array}$ & $\begin{array}{l}\text { residents } \\
\text { characteristic } \\
\text { studied }\end{array}$ & $\begin{array}{l}\text { geographical } \\
\text { consequences } \\
\text { studied }\end{array}$ \\
\hline $\begin{array}{l}\text { (E. J. Kim \& } \\
\text { Miller, 2017) }\end{array}$ & $\begin{array}{l}\text { evaluation of } \\
\text { scenes }\end{array}$ & $\begin{array}{l}\text { preconception, } \\
\text { health concerns }\end{array}$ & 200 & none & none \\
\hline $\begin{array}{l}\text { (Loures, } \\
\text { Panagopoulos, } \\
\text { \& Burley, 2016) }\end{array}$ & $\begin{array}{l}\text { evaluation of } \\
\text { post-industrial } \\
\text { land } \\
\text { transformations }\end{array}$ & $\begin{array}{l}\text { resident and } \\
\text { geographical } \\
\text { characteristic }\end{array}$ & 450 & $\begin{array}{l}\text { age, gender, } \\
\text { school level }\end{array}$ & $\begin{array}{l}\text { parish of } \\
\text { respondent } \\
\text { origin }\end{array}$ \\
\hline $\begin{array}{l}\text { (Rink \& Arndt, } \\
\text { 2016) }\end{array}$ & $\begin{array}{l}\text { evaluation of } \\
\text { successive stages } \\
\text { of scenes } \\
\text { (acceptance, } \\
\text { perception of } \\
\text { threats, of } \\
\text { usability, } \\
\text { possible } \\
\text { activities) }\end{array}$ & n.a. & 281 & none & none \\
\hline $\begin{array}{l}\text { (Kunc, } \\
\text { Martinat, } \\
\text { Tonev, \& } \\
\text { Frantal, 2014) }\end{array}$ & $\begin{array}{l}\text { perception of } \\
\text { brownfields }\end{array}$ & two cities & $381+321$ & none & two cities \\
\hline $\begin{array}{l}\text { (Kunc, Navratil, } \\
\text { et al., 2014) }\end{array}$ & $\begin{array}{l}\text { perception of } \\
\text { risks connected } \\
\text { with brownfield, } \\
\text { preferences for } \\
\text { revitalization }\end{array}$ & $\begin{array}{l}\text { location of } \\
\text { brownfield, } \\
\text { resident } \\
\text { characteristic }\end{array}$ & not stated & $\begin{array}{l}\text { age, tender, } \\
\text { level of } \\
\text { education }\end{array}$ & $\begin{array}{l}\text { distance to } \\
\text { brownfield } \\
\text { prior to } \\
\text { regeneration }\end{array}$ \\
\hline $\begin{array}{l}\text { Maliene, } \\
\text { Wignall, \& } \\
\text { Malys, 2012) }\end{array}$ & $\begin{array}{l}\text { benefits and } \\
\text { attractiveness of } \\
\text { brownfield } \\
\text { regeneration }\end{array}$ & two cities & $50+50$ & none & two cities \\
\hline $\begin{array}{l}\text { (Doucet, van } \\
\text { Kempen, \& van } \\
\text { Weesep, 2011a) }\end{array}$ & $\begin{array}{l}\text { perception of } \\
\text { regenerated } \\
\text { brownfield }\end{array}$ & $\begin{array}{l}\text { geographical } \\
\text { consequences, } \\
\text { age of } \\
\text { respondents }\end{array}$ & 364 & age & $\begin{array}{l}\text { far/close, high- } \\
\text { income/low- } \\
\text { income, } \\
\text { two regenerated } \\
\text { brownfields }\end{array}$ \\
\hline $\begin{array}{l}\text { (Greenberg, } \\
\text { Craighill, } \\
\text { Mayer, Zukin, } \\
\text { \& Wells, 2001) }\end{array}$ & $\begin{array}{l}\text { willingness to } \\
\text { move to housing } \\
\text { built on } \\
\text { brownfield sites }\end{array}$ & $\begin{array}{l}\text { resident } \\
\text { characteristic }\end{array}$ & 779 & $\begin{array}{l}\text { age, gender, } \\
\text { income }\end{array}$ & none \\
\hline
\end{tabular}

Kim and Miller (E. J. Kim \& Miller, 2017) studied preferences for different brownfield scenes of residents for nearby brownfield sites. Six types of brownfield regeneration were examined - historical landmarks and maintained landscapes with scattered structures received the highest ratings, scenes with scruffy vegetation and plain modest rundown buildings revealed mixed preferences, and scenes with industrial remnants and crumbling industrial remnants were preferred the least. Impact of both residents' characteristic and geographical consequences were not studied.

Loures et al. (Loures et al., 2016) studied factors in landscape reclamation of resident of Lagoa, Portugal. Their main aim was to evaluate structure behind preferences for different regeneration of brownfield. The differences among residents' characteristic as well as 
geographical consequences were not tested; however, it is evident from the table 4 there were great differences in perception especially regarding culture and safety among age categories as well as gender. It also seems that important differences are for mobility/accessibility item among places of residents' origin.

Rink and Arndt (Rink \& Arndt, 2016) examined preferences for different successional stages of spontaneous succession and of afforestation on abandoned brownfield site in Leipzig, Germany. Households in six urban districts were selected as respondents of the survey. Authors did not test the differences possibly caused by the place of respondents' origin.

Kunc et al. (Kunc, Martinat, et al., 2014) aimed their study to the comparison of two cities. Factor compared were: awareness, urgency, rate of apprehension, brownfield regeneration policy, the most problematic localities and best practices. They found that the both cities are quite different in selected aspect. Strong negative perception by Ostrava residents in comparison to Brno residents was found. Brownfield policies as applied have caused more polarization of opinion in Ostrava than in Brno. Thus, the city is found as important factor of perception of brownfields, however, this differences were not tested by the authors.

Kunc et al. (Kunc, Navratil, et al., 2014) studied diversified structure of residents perception of South Centre of Brno, Czech Republic. They found that women are more sensitive towards environmental risks, and that younger respondents are more tolerant regarding drug dependency issues. Permanent residence distance from the studied area shows correlation for perception of air contamination by responders, who live closer to the South Centre. Gender as well as age were found not to be statistically important for preferences for new activities in South Centre. Negative correlation was identified between the locations of new usage as public recreation area.

Maliene et al. (Maliene et al., 2012) prepared detailed comparison of two waterfront brownfields - Liverpool, UK and Cologne, Germany. Results of questionnaire survey shows that regenerations are in both cities perceives as generally positive, but found was different level of satisfaction - results from Cologne were not as conclusive as Liverpool. Generally, the German public doubted that any of the city's economic and social factors would greatly benefit from the brownfield regeneration.

Doucet et al. (Doucet et al., 2011a) had concerned their work in testing the impact of geographical consequences on perception of the flagship waterfront regeneration the Kop van Zuid in Rotterdam, Netherlands. Spatial proximity was found to be the key factor influencing perception of particular brownfield regeneration. Age was also studied as predictor of 
differences in perception of brownfield regeneration. Strong feelings of attachment towards a new flagship would diminish with older age groups. Authors found that both geographical consequences and residents characteristic are of importance for preferences for brownfield regeneration. However none of them were tested for statistical importance.

Greenberg et al. (Greenberg et al., 2001) studied willingness to move to housing built on brownfield sites in New Jersey, USA. Respondents thinking of moving to regenerated brownfield were relatively poor and young.

The above mentioned results of previous studies imply the importance of both the characteristic of respondents and the respondents' residence for their perception of various issues of brownfields regeneration. Researches bring miscellaneous results as for the respondents 'preferences for brownfield regenerations depending on location and character of particular brownfields under study.

Characteristics of respondents have been used as explaining variables disproportionately more often than characteristics related to the respondents' place of residence - in spite of the fact authors perceive the impact of the place of residence to be decidedly important (see the selection of respondents in most of studies.

\section{MATERIAL AND METHODS}

All data necessary to comply with the set objective were collected in a primary research by means of a questionnaire survey on a $1 \%$ representative sample.

\section{Geographical data}

The research was carried out among the citizens of two cities - Karviná and České Budejjovice. These cities were selected in order to the meet the target of the paper particularly identification of influence of various variables on the responders' answers in the survey of preferences of brownfields revitalization. Difference of attitudes of citizens of different towns and cities to the regeneration of brownfields has been already proved in the past (Kunc, Martinat, et al., 2014).

Karviná is a city located in the mining region in the eastern part of the Czech Republic. It has been city build on heavy industry and mining for the last 150 years. The recent development resulted in massive decline in population and high increase in the number of industrial brownfields (Martinat, Cyronova, Dvorak, \& Klusacek, 2014; Martinat et al., 2016). 
Brownfields represents in Karviná a great barrier for further development (Tureckova, Skrabal, Benda, \& Martinat, 2016).

České Budějovice has been an important economic and regional centre of South Bohemian region of the Czech Republic. Brownfields in České Budějovice are mostly the former military sites and abandoned industrial objects. Many of them were already successfully redeveloped into shopping centres, administrative buildings or blocks of flats. Brownfields do not pose any important problem for the town development (Wernerova, 2008).

The 1\% sample of residents in each city means 559 respondents from Karviná and 935 from České Budějovice. Final number of collected responses was from 497 residents from Karviná (which means a refusal rate of 9.0\%) and 833 from České Budějovice (which correspond to a refusal rate of $10.9 \%$ ).

The previously reported results state the place of survey to be an influencing factor for the perception of regeneration in a town (Doucet et al., 2011a; Doucet, van Kempen, \& van Weesep, 2011b; Kunc, Navratil, et al., 2014). That is why each of the two cities was subdivided into three parts, in which respondents were questioned separately. Those parts were (i) city center including historic core with surrounding areas originated particularly in 19th century and the first half of 20th century; (ii) vicinity of the center encompassing particularly panel housing estate from the second half of 20th century; and (iii) peripheral surroundings of the city, i.e. areas representing an urbanized area, having however a rather rural character for it is a matter of original villages that have been absorbed by the city (Haggett, 2001). Numbers of respondents corresponded to the proportion of the citizenship in particular parts of each city.

\section{Respondent data}

The target group of the survey was the citizens of age (18 years and more). Respondents were invited to state some biological and socio-economical characteristics that could be related to the preference for brownfield regeneration. The first group represented gender (a bivariate variable, woman/man) and age (proportional variable, age expressed as number of years) and the second group encompassed household income (ordinal variable) and educational background (proportional variable/number of years of education); 
Table 2 Data for respondents

\begin{tabular}{lcc}
\hline & Karviná & České Budějovice \\
\hline gender & & \\
female & $53.92 \%$ & $51.50 \%$ \\
male & $46.08 \%$ & $48.50 \%$ \\
\hline age (mean) & 36.65 years & 42.18 years \\
\hline education (mean) & 13.43 years & 13.78 years \\
\hline income & & \\
up to 15000 CZK & $10.66 \%$ & $9.24 \%$ \\
$15000-20000$ CZK & $14.89 \%$ & $13.21 \%$ \\
$20000-25000$ CZK & $18.31 \%$ & $14.05 \%$ \\
$25000-30000$ CZK & $19.52 \%$ & $15.97 \%$ \\
$30000-35000$ CZK & $10.26 \%$ & $15.73 \%$ \\
$35000-40000$ CZK & $10.46 \%$ & $13.21 \%$ \\
$40000-45000$ CZK & $6.44 \%$ & $6.96 \%$ \\
$45000-50000$ CZK & $4.23 \%$ & $5.88 \%$ \\
more than 50 000 & & \\
CZK & $5.23 \%$ & $5.76 \%$ \\
\hline $\mathrm{n}$ & 497 & 833 \\
\hline
\end{tabular}

\section{Perception of brownfield regeneration}

Perception of brownfield regeneration was studied similarly in three parts of the cities: (i) city center; (ii) vicinity of the center; and (iii) peripheral surroundings of the city. Possibilities of brownfield regeneration are immensely varied (Otsuka, Dixon, \& Abe, 2013). Moreover the brownfields markedly vary according to the original use of the property, particularly between built-up area and compound in city surroundings (Frantal et al., 2015; Krejci, Dostal, Havlicek, \& Martinat, 2016). For that reason two lists of brownfields were made - one for the brownfields in city centers and in vicinity of the center and another one for those in peripheral surroundings of the city.

The list of possible use for center and vicinity of the center included nine items: park, sports venue, apartment houses, commercial center, amusement center, industrial production, shopping arcades with apartments in upper floors, tourist accommodation (hotel, pension and the like), parking. The list for peripheral surroundings of the city included six items: restoration in the nature-like state, dumps, factory premises construction, starting a park, construction of an outdoor swimming facility, sports venue construction.

Respondents were asked to "state the degree of their agreement with the possibilities of brownfield regeneration". The degree of agreement with each possibility of brownfields regeneration was measured separately for each part of the studied city. This request resulted 
into the list of statement on 24 items of regeneration possibilities. The degree of agreement was measured by means of a 4-point scale with the following options: 1=strongly disagree, $2=$ rather disagree, $3=$ rather agree, $4=$ strongly agree.

\section{Statistical Analysis}

Statistical processing draws on character of collected data and determined objective. Our aim was to assess the structure of preferences for the particular type of brownfield regeneration in different parts of cities. Since it represents groups of explained variables, the statistical processing should be based on multidimensional statistical methods (Robinson, 1998). Basic methods for such an assessment are Principal Component Analysis (PCA) and correspondence analysis (Quinn \& Keough, 2002). The use of one of those methods is given particularly by the identified length of gradient calculated in multiples of the standard deviation (ter Braak \& Smilauer, 2012). In our case here, the length was 1.1; we have used PCA then. To make the responses for dependent variables relative the preferences were centered prior the analyses. Since our objective is not only to assess the structure behind the preferences for the particular type of brownfield regeneration, but primarily to identify the relation of this structure on the character of respondents, the potential link between the structure of preferences and all studied independent variables was initially assessed based on biplot (ter Braak \& Smilauer, 2012). The latter graph allows us to assess the mutual relation among explained variables and explaining variables that are passively projected into coordinates that are given by the structure of the explained variables.

However, the biplot based on results of PCA analysis of dependent variables is only a graphic representation without any possibility of statistical testing of the relations. In case we would like to test those relations, the employment of unconstrained method is necessary. For this reason the relation between the structure of dependent variables and the structure of independent variable was tested using Redundancy Analysis (RDA), which is an unconstrained extension of PCA analysis (Leps \& Smilauer, 2003). Since we assume not all measured independent variables have to be statistically significant for the structure of preferences for brownfields regeneration, the RDA model encompassed only those variable contributing statistically significantly to the degree of explained variation of dependent variables. The selection was made by means of the method of forward selection of independent variables. Statistical significance was tested using Monte Carlo permutation test (ter Braak \& Smilauer, 2012) that is based on testing a hypothesis of the non-existence of 
differences between the structure of collected date and the structure of randomly arranged values of data (Good, 1995); 999 permutation (i.e.999 randomly arranged data) was used.

Results of the previous studies clearly show an existing influence of a larger number of variables on the perception of regenerations. Those, as mentioned above, are possible to divide into two different groups - variables connected with the respondent of the survey and variables connected with the place of survey. Results of RDA analysis show us a partial importance of those two groups of variables - particularly of the explained variation that is shared commonly by both those groups. Afterwards the analysis of two separate groups of independent variables - respondents' characteristics and location variables - was done. Variation Partioning for Two Groups was used in order to identify the importance of those two groups and their intersection for the preference for structure of particular possibilities of brownfield regeneration (Legendre \& Legendre, 2012). Again the RDA analysis was employed with the same settings and a comparison of particular RDA models was done separately for respondents' characteristics and for location variables.

All calculations of multidimensional analyses were done with the software CANOCO 5.0 (ter Braak \& Smilauer, 2012); the implemented tool Var-part-2groups-Simple-effect was used for Variation Partioning (ter Braak \& Smilauer, 2012).

\section{RESULTS}

The process of data treatment and analysis included three stages - (i) unconstrained multivariate analysis of dependent variables with passive projection of independent variables; (ii) constrained multivariate analysis with forward selection of independent variables statistically significant for the model; and (iii) variation partitioning for two groups of independent variables.

Three groups of regeneration of brownfields were identified in the first analysis (= PCA). Those groups have been named according the dependent variables as follows: industry, trade and housing, and sports and green areas (Figure 1). A completely separate group is "fun". On the contrary, it did not show in any way a tendency to create gradients associated with the place of localization of brownfields. Three main groups of variables correlate fairly well with the first two axes of the PCA. With the first axis of PCA (1st PCA axis explains $20.1 \%$ of variation in the dependent variables data) correlate best with the types of regeneration associated with residential and business features. In contrast, the regeneration of the restoration to the "natural" form hand in hand with sports types of usage are closest to the 
other PCA axis (2nd PCA axis explains $12.2 \%$ of variation in the dependent variables data). Against these kinds of regeneration industrial regeneration types are distinguished along the second axis. Explaining variables were projected into the ordination diagram (biplot). From their positions in the ordination diagram, we can conclude that there is a link in the structure of preferences, types, and the areas of origin of the respondent.

On the opposite side of the 1st PCA gradient than where grow preferences for residentialbusiness function of regeneration, is the origin of the respondent from the peripheral surroundings of the city. Against it - along the first axis of PCA - stands the origin of the respondent from the core of the city. By contrast, it came to the distinguishing of respondents from Karviná and from České Budějovice as well as men and women along a gradient of 2nd PCA axis

Figure 1 Biplot of dependent and independent variables under study. Results of PCA; first two axes shown

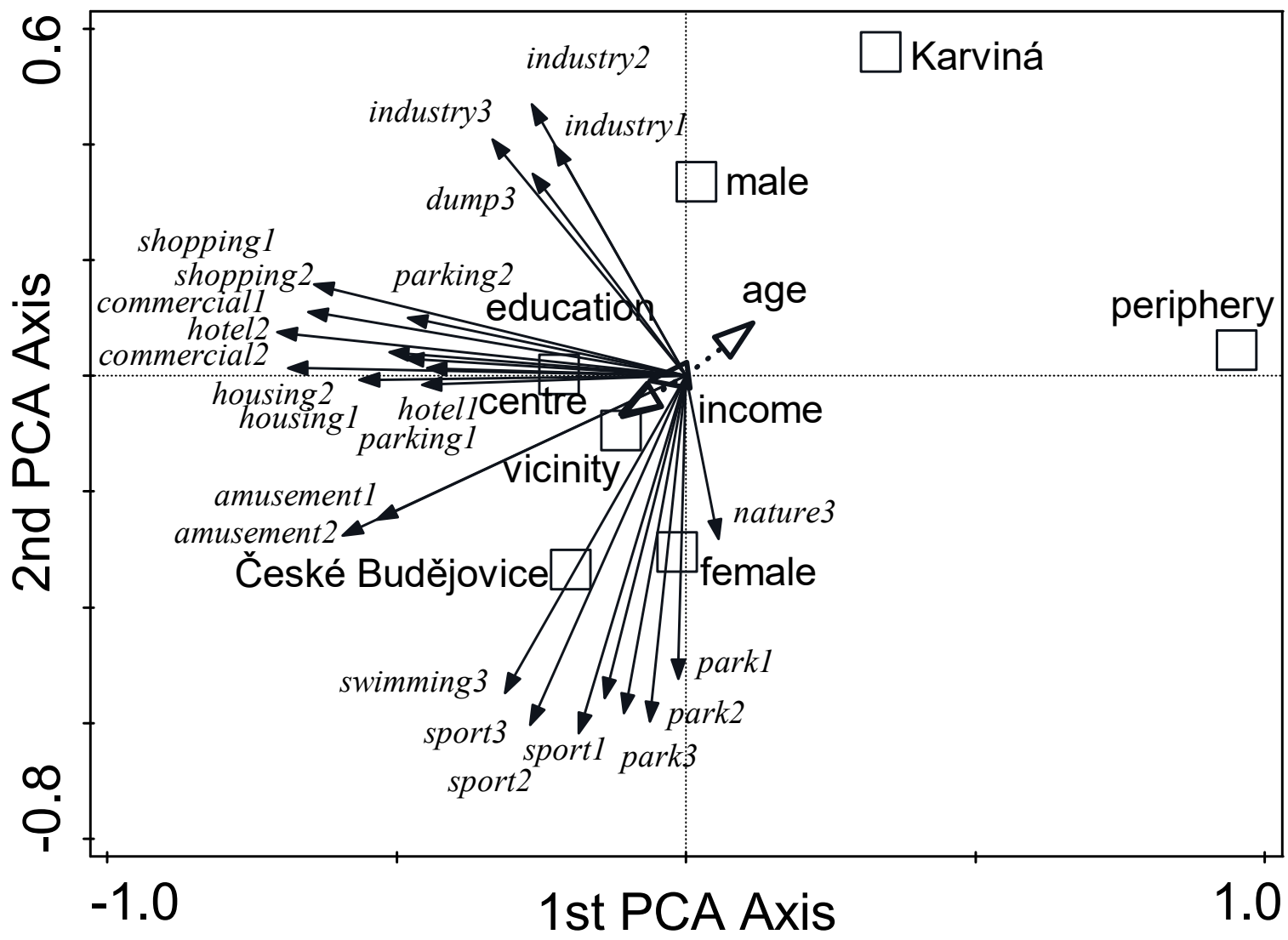

Notes: Dependent variables are in italics; city centre $=1$, vicinity of the centre $=2$, periphery of the city $=3$; for city centre and vicinity: park $=$ park, sport $=$ sports venue, housing $=$ apartment houses, commercial $=$ commercial centre, amusement $=$ amusement center, industrial $=$ industrial production, shopping $=$ shopping arcades with apartments in upper floors, hotel = tourist accommodation (hotel, pension and the like), parking = parking; for periphery: nature $=$ restoration in the nature-like state, dumps $=$ dumps, industry $=$ factory premises construction, park $=$ starting a park, swimming $=$ construction of an outdoor swimming facility, sport $=$ sports venue construction. 
The statistical link between independent and dependent variables can, however, could be specified only by means of the constrained analysis. RDA has identified the statistical significance (at least $\mathrm{p}<.05$ ) of the influence of all explaining variables on structure of preferences for brownfields regeneration, with the exception of household income (Figure 2, Figure 3). The clearly most important variable explaining the largest part of the explainable variation of the structure of preferences for brownfields regeneration of is a city of origin of the respondent (36.8\%). An above-average rate of variation in the forest explained dependent variables was concluded only in case of age $(24.8 \%)$ and of the area of origin of the respondent within the city $(22.1 \%)$.

Figure 2 Biplot of independent variables under study. Results of RDA; first two axes shown; only significant independent variables entered RDA

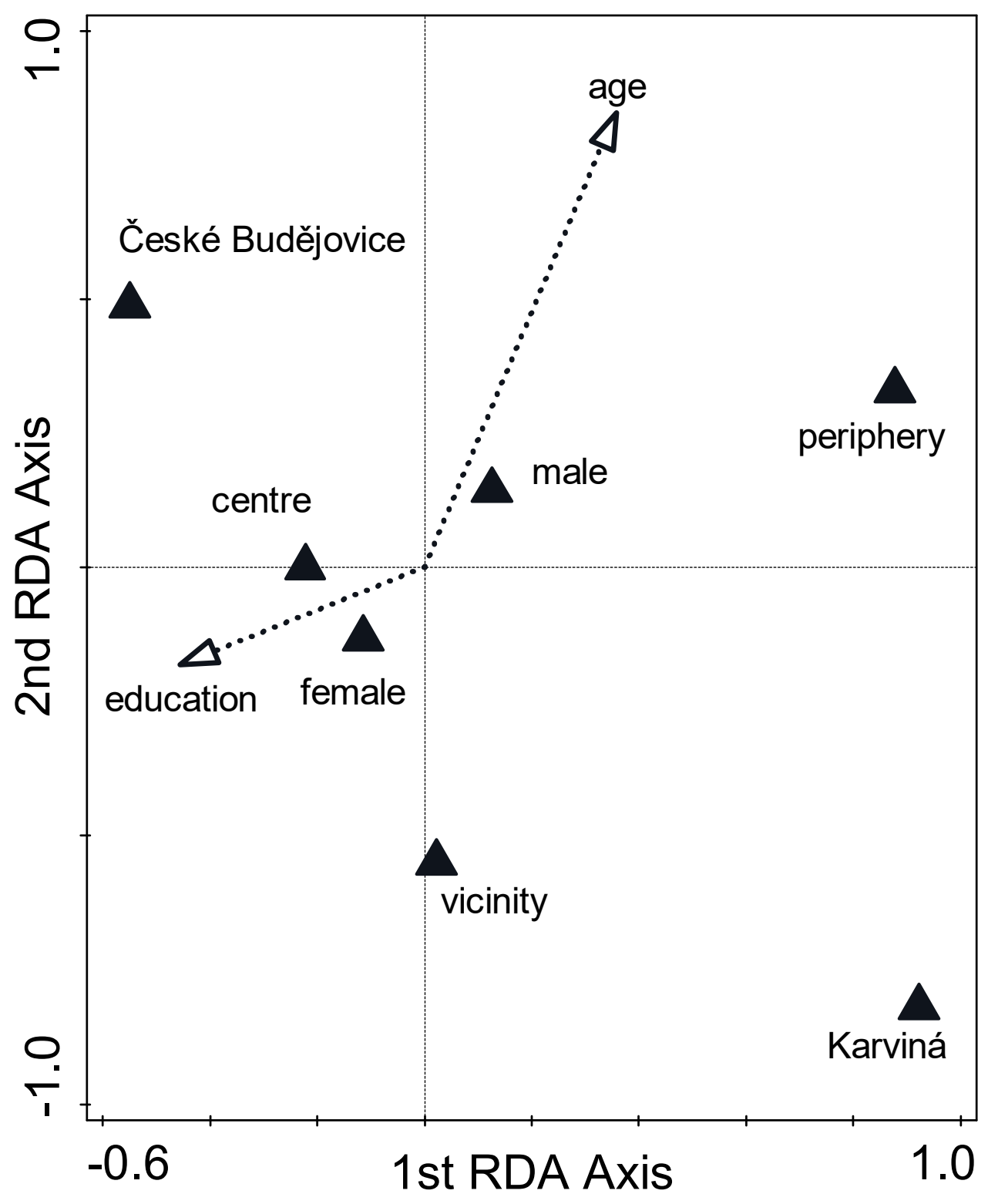


Figure 3 Biplot of dependent variables under study. Results of RDA; first two axes shown.

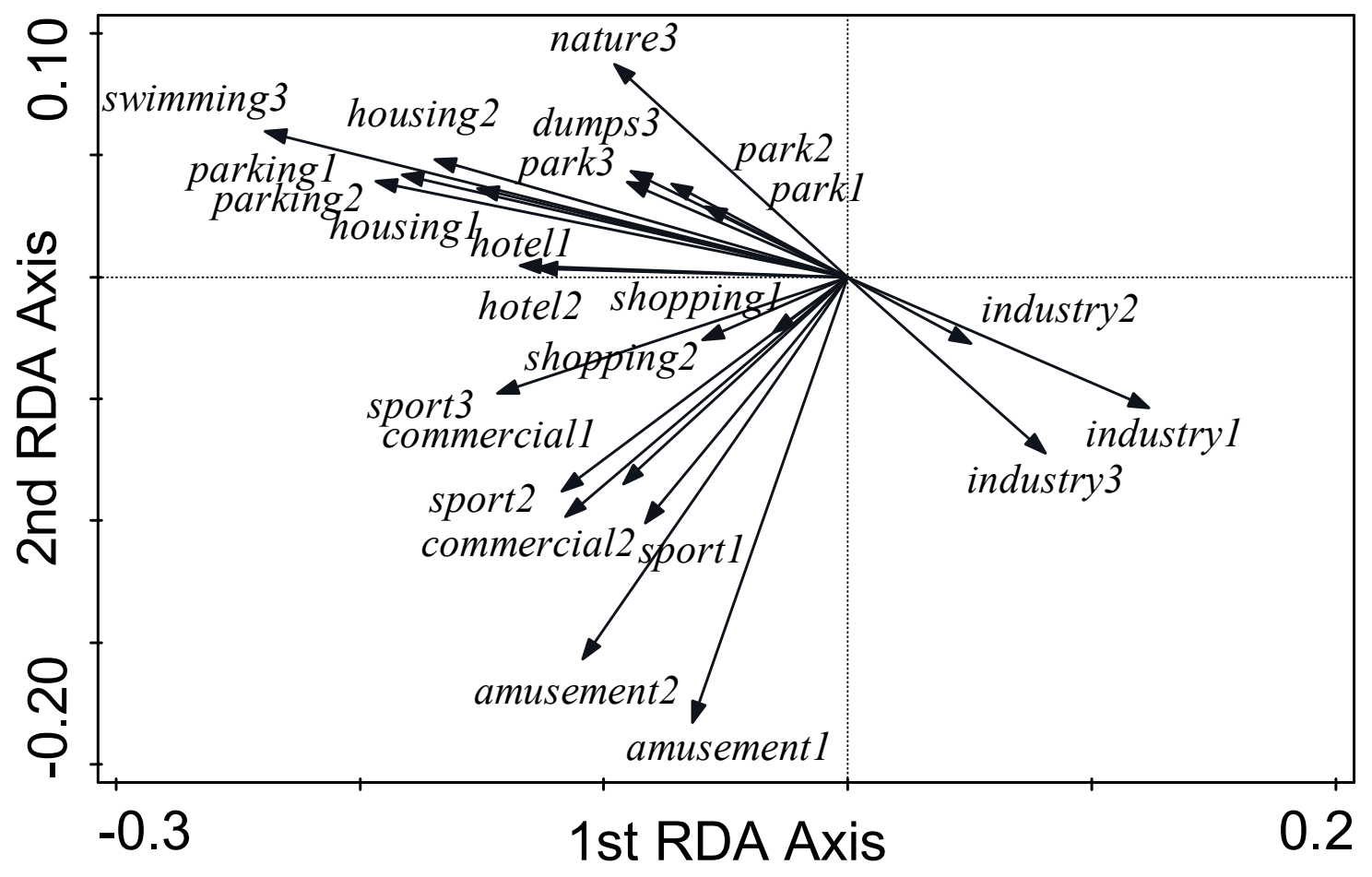

For notes please see Figure 1

The model of the RDA selected with one sole exception all studied variables. Since those variables belong to the group of variables that are related to the place of the respondent, a third test was performed with the aim to identify the relevance of both groups for explaining the variability in the responses of the responders to the preferences of the regeneration of brownfields. The result of the comparison of the two in parallel made RDA models (Figure 4) showed that the variability of the structure of preferences is statistically significantly explained by both the combination of all of the variables $(F=5.4 ; p<0.001)$, and the group of variables that characterize the respondent $(F=4.3 ; p<0.001)$ and a group of variables related to point $(F=6.9 ; \mathrm{p}<0.001)$. It follows that the location factors are statistically more significant elements of the influence on the structure of the preferences of the regeneration of brownfields. Adjusted variation explained is higher for localization variables (share = 56.6; proportion of total adjusted variation of $1.3 \%$ ) than for the variables describing the inhabitants ( share $=41.6$; proportion of the total adjusted variation of the $0.9 \%$ ). Quite surprisingly, the size of the shared variability is negligible ( share $=1.9 \%$ ). 
Figure 4 Results of Variation Partitioning (comparison of two simultaneous RDA)

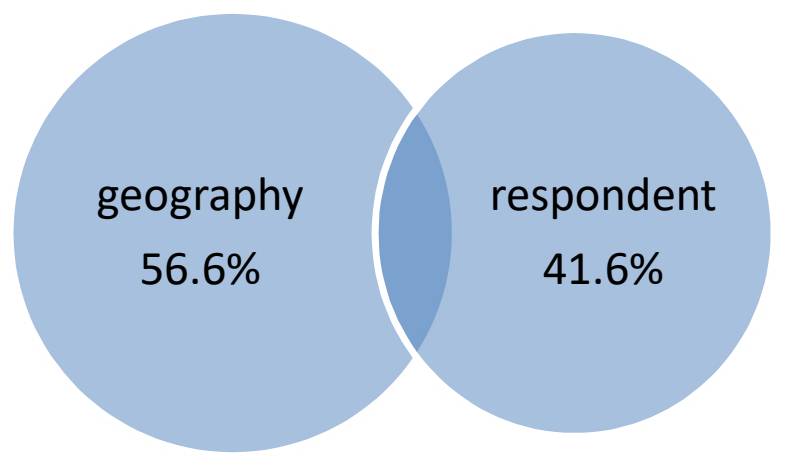

\section{DISCUSSION}

Multidimensional analysis of potential types of regeneration of brownfields in three specific areas of city made us to identify four closed group of brownfields regeneration - green/sport, housing/shopping, industry, and entertainment. Indirect ordination analysis has statistically proven that this differentiation is influenced by both the variables related to the respondent and the variables spatially oriented. From a larger amount of results the most interesting include: (1) preference for commercial-residential use of brownfields has a distinctive centreperiphery distribution, (2) preferences for the regeneration in the way of the reactivation of the industry are different between cities, (3) the effects of both types of variables (characteristics of the respondent and the place of survey) is significant, however, shared explainable variation is negligible.

\section{Housing and shopping preferences}

From the perspective of spatial structure of the city (Sykora \& Mulicek, 2017), the most interesting result is the spatial aspect of perception of regeneration into a housing and shopping possibilities. This gradient in the analyzed data was identified in the PCA, as well as the RDA analysis. In both cases, it significantly correlates with the first axes of PCA and RDA. The position of the variable "place of survey" (city center- vicinity of the center peripheral surroundings of the city) also correlates with the first axes of the PCA and the RDA. Higher level of preferences is among the residents of the city center, lower level was found in the population of the vicinity of the center and very low for the population of the peripheral surroundings of a city. So the inhabitants of city centers, when deciding on the suitability of the regeneration of brownfields, prefer the types of housing and shopping, and that in all parts of the city. In case of the population of peripheries of the cities it is the opposite. 
It may be related to a perceived lack of housing on the part of inhabitants of city centers, which is usually caused by the price of housing (Ourednicek, Pospisilova, Spackova, Kopecka, \& Novak, 2016) and can lead to the urban shrinking (Haase, Bernt, Grossmann, Mykhnenko, \& Rink, 2016). Restoration of the residential function is then one of the basic tools of reurbanization (Haase, Herfert, Kabisch, \& Steinfuhrer, 2012). This attitude may then increase the pressure on the processes of gentrification (Brade, Herfert, \& Wiest, 2009; Rogatka, Chodkowska-Miszczuk, Bieganska, Sroda-Murawska, \& Grzelak-Kostulska, 2016) and the creation of a business-commercial-residential blocks in the center of cities and their immediate vicinity (Bierzynski et al., 2011).

On the contrary, that lack of housing is not perceived on the periphery of cities. It may be related to processes of suburbanization that significantly interfere with social environment (Szczepanska, 2016) of rather rural or even traditional structures in peripheries of cities (Chodkowska-Miszczuk, 2014; Holesinska \& Bobkova, 2015; Krzysztofik, Kantor-Pietraga, Runge, \& Sporna, 2017; Novotny, Csachova, Kulla, Nestorova-Dicka, \& Pregi, 2016; Nuga, Metspalu, Org, \& Leetmaa, 2015). Construction of suburbia, which is usually affected by property developers and the banks rather than the local management, is generally seen more as a problem (Kahrik, Leetmaa, \& Tammaru, 2012). Likewise, it is not very popular among residents of city surroundings, which is true even for cities under study (Kubes, 2015).

The problems of the construction of shopping centers are important in the area of postsocialist cities, as it fundamentally changed the spatial buying behavior of large cities and their hinterland (Klapka, Erlebach, Kral, Lehnert, \& Micka, 2013; Kunc, Frantal, Tonev, \& Szczyrba, 2012; Szczyrba \& Fiedor, 2014). Shopping centers are often built on greenfields in a distance from an urbanized area of the city itself (Kunc, Krizan, Bilkova, Barlik, \& Maryas, 2016; Maryas, Kunc, Tonev, \& Szczyrba, 2014).

\section{Industry preferences}

A large number of brownfields in towns and cities has an industrial history (Frantal et al., 2015; Krzysztofik, Tkocz, Sporna, \& Kantor-Pietraga, 2016; Longo \& Campbell, 2017; Stasakova \& Kulla, 2016). It is related to the processes of deindustrialization (Van Kempen \& Murie, 2009) that affected in Europe particularly the cities of Eastern and Southeastern Europe (Heidenreich, 1994; Lorber, 2014), still grappling with a weak degree of competitiveness after the fall of the iron curtain and the controlled economy (Ianos, 2016). This deindustrialization in the major cities of the CEE countries is still in progress, unlike some rural spaces, where even the factors of "reindustrialization" appeared (Lengyel, Vas, 
Kano, \& Lengyel, 2017). Still, there are urban spaces, where "reindustrialization" is one of the significant elements of economic development. These areas are primarily "old" industrial areas - a typical example of CEE realm is Katowice conurbation, Poland, which is an area with original concentration of heavy industry associated with the mining of black coal (Krzysztofik, Kantor-Pietraga, \& Sporna, 2013). Reindustrialization physically happened and going on especially in the automotive sector (Krzysztofik et al., 2016) and benefits from the cheap labor (Molnar, 2016).

In general, the former industrial complexes are the most commonly revitalized back into the form of industrial areas, however, the less risky areas are often also revitalized into a residential premises (Schwarz, Depken, Hanning, \& Peterson, 2009). The revitalization of brownfields into a form of industrial use is specific in a complexity of influences on the decision-making process of a particular revitalization as economic, urbanistic and environmental criteria were found to be equally important for redevelopment to the industrial area (Burinskiene et al., 2017).

The regeneration into industrial sites has low support of the local population (Greenberg \& Lewis, 2000; E. J. Kim \& Miller, 2017) and low environmental value (Lafortezza, Corry, Sanesi, \& Brown, 2008). On the other hand, it is a supported alternative from the perspective of state and local authorities, for it is an important element of development (Osman, Frantal, Klusacek, Kunc, \& Martinat, 2015).

In our research, the support to the reidustrialization is clearly associated to the city. While in České Budějovice it is low, it is high in Karviná. This difference may be related to the nature of brownfields in both cities and with the problem of the industrial history and background of the town (Rall \& Haase, 2011). While Karviná is a typical city in the industrial region of Ostrava (Mulkova, Popelka, \& Popelkova, 2016) with high unemployment caused by the decline of industrial production (Martinat et al., 2016), České Budějovice is a city, albeit with a significant industrial history, where the deindustrialization did not fundamentally badly reflected on the socio-economic environment of the city (Wernerova, 2008). The structure of preferences depends then on the specific state of affairs of the place (in our case), in which the research is conducted.

\section{Respondent vs. location}

From the methodological point of view of research on perception of brownfields, the most interesting is the result of variation partitioning. The structure of preferences is explainable by 
variables related with the characteristics of the respondent, and with the place where the respondent comes from. This finding itself is not too striking and it is assumable. A surprising result is a very small part of the jointly explained variability.

As mentioned above, a more important variable on the side of the variables associated with the place is the city of survey. So the inhabitants of different cities perceive their problems differently the specificity of the space is reflected in the responses of responders. Therefore, when making results from one city, we cannot automatically conclude the general validity of the responses of the respondents. On the other hand, it means that residents of a city perceive the issue of brownfields in relation to the situation of the city in which they live and have therefore a "relationship" to particular brownfields. Brownfields in both cases are not something that is strange for their own citizens, even if the degree of awareness among the population is very low. Even the second of used explaining variables associated with a location (the location of the questioning) has proven to be significant.

While the city is indicative for the perception of the importance of industrial sites and regeneration into free green spaces allowing sports activities, interviewing site in a city makes the affection of the respondent to the regeneration into a form of residential and business functions.

Both variables associated with the site of interviewing are more important for the explainable part of the structure of respondents answers as for their preferences for the type of regeneration of brownfields - they explain 1.36 times the value of the explained variability by the variables associated with the characteristics of the respondent.

The characteristics of the respondent, therefore, have less importance for the structure in the responses of the respondents. More important among the studied variables is particularly the age. This variable is then able to explain the last of four identified groups of preferences for brownfields regeneration, i.e. entertainment. Entertainment is more preferred by younger respondents. However, even other variables associated with the characteristics of the respondent have their importance for understanding variability in the responses - women more often than men prefer the type of regeneration into green/sport and entertainment. These types of regeneration are also more preferred by respondents with higher education.

\section{CONCLUSION}

We have succeeded, on examples of residents of two cities and originating from three parts of those cities, to identify four main factors in preferences the target use of brownfields. 
However, their identification did not belong to the main objectives of this paper. Our target was primarily to assess the importance of the two groups of variables on such perception. The analyses of our research between residents imply that there is a statistically significant effect of variables from both categories on the structure in the preferences of residents. More significant is the effect of geographic variables - where the respondent comes from (from what city and what part of the city). The intersection of the influence of variables from both groups is negligible.

From a practical point of view, one of particular interesting finding is mainly the support to the reindustrialization, which is clearly linked with the city. A high support is in the city, where the industry (particularly heavy) and mining of hard coal represented the leading economic activity. Industrial (recent) history affects then the interest of the inhabitants in reindustrialization regeneration of brownfields. The second specific finding is the relation between place of residence of inhabitants and their preferences for regeneration into the form of housing and shopping. It has its importance primarily for planning the development of different sectors of the city.

\section{Acknowledgments}

The research was supported by institutional funding from University of South Bohemia (J.N.), by the project No. IGS10A1 "Aspects and preconditions of the sustainable development of region in the context of business opportunities" at the Faculty of Economics, University of South Bohemia in České Budějovice (K.P.), by the project Brownfields in urban and rural space: geographic, economic, historical, legal contexts and their importance for regional development (BURAN) nr. SGS/21/2016 (S.M.), and by the project Geography of recycling of urban space that was funded by the Czech Science Foundation, nr. 17-26934S (P.K.). We thank all who participated anyway in our survey.

\section{REFERENCES}

Alexandrescu, F., Martinat, S., Klusacek, P., \& Bartke, S. (2014). The Path From Passivity Toward Entrepreneurship: Public Sector Actors in Brownfield Regeneration Processes in Central and Eastern Europe. Organization \& Environment, 27(2), 181-201. doi:10.1177/1086026614529436

Alexandrescu, F., Rizzo, E., Pizzol, L., Critto, A., \& Marcomini, A. (2016). The social embeddedness of brownfield regeneration actors: Insights from social network analysis. Journal of Cleaner Production, 139, 1539-1550. doi:10.1016/j.jclepro.2016.09.007

Berki, M. (2017). Perceived space, conceived space, lived space: The trialectics of spatiality on the example of a brownfield regeneration investment in Budapest. Ter Es Tarsadalom, 31(2), 23-43. doi:10.17649/tet.31.2.2844

Bierzynski, A., Grabkowska, M., Haase, A., Klusacek, P., Maas, A., Mair, J., . . Z Zapletalova, J. (2011). Lodz, Gdansk, Brno and Ostrava and their Inner Cities: Urban and Demographic Development during Post-socialism. Residential Change and Demographic Challenge: the Inner City of East Central Europe in the 21st Century, 101-140. 
Brade, I., Herfert, G., \& Wiest, K. (2009). Recent trends and future prospects of socio-spatial differentiation in urban regions of Central and Eastern Europe: A lull before the storm? Cities, 26(5), 233-244. doi:10.1016/j.cities.2009.05.001

Burinskiene, M., Bielinskas, V., Podviezko, A., Gurskiene, V., \& Maliene, V. (2017). Evaluating the Significance of Criteria Contributing to Decision-Making on Brownfield Land Redevelopment Strategies in Urban Areas. Sustainability, 9(5). doi:10.3390/su9050759

Chodkowska-Miszczuk, J. (2014). Small-scale renewable energy systems in the development of distributed generation in Poland. Moravian Geographical Reports, 22(2), 34-43.

Doick, K. J., Sellers, G., Castan-Broto, V., \& Silverthorne, T. (2009). Understanding success in the context of brownfield greening projects: The requirement for outcome evaluation in urban greenspace success assessment. Urban Forestry \& Urban Greening, 8(3), 163-178. doi:10.1016/j.ufug.2009.05.002

Doucet, B., van Kempen, R., \& van Weesep, J. (2011a). Resident Perceptions of Flagship Waterfront Regeneration: The Case of the Kop Van Zuid in Rotterdam. Tijdschrift Voor Economische En Sociale Geografie, 102(2), 125-145. doi:10.1111/j.14679663.2010.00611.x

Doucet, B., van Kempen, R., \& van Weesep, J. (2011b). 'We're a rich city with poor people': municipal strategies of new-build gentrification in Rotterdam and Glasgow. Environment and Planning A, 43(6), 1438-1454. doi:10.1068/a43470

Frantal, B., Greer-Wootten, B., Klusacek, P., Krejci, T., Kunc, J., \& Martinat, S. (2015). Exploring spatial patterns of urban brownfields regeneration: The case of Brno, Czech Republic. Cities, 44, 9-18. doi:10.1016/j.cities.2014.12.007

Franz, M., Gueles, O., \& Prey, G. (2008). Place-making and 'green' reuses of brownfields in the Ruhr. Tijdschrift Voor Economische En Sociale Geografie, 99(3), 316-328. doi:10.1111/j.1467-9663.2008.00464.x

Good, P. (1995). Permutation Tests: A Practical Guide to Resampling Methods for Testing Hypotheses. New York: Springer.

Greenberg, M., Craighill, P., Mayer, H., Zukin, C., \& Wells, J. (2001). Brownfield redevelopment and affordable housing: A case study of New Jersey. Housing Policy Debate, 12(3), 515-540.

Greenberg, M., \& Lewis, M. J. (2000). Brownfields redevelopment, preferences and public involvement: A case study of an ethnically mixed neighbourhood. Urban Studies, 37(13), 2501-2514. doi:10.1080/00420980020080661

Haase, A., Bernt, M., Grossmann, K., Mykhnenko, V., \& Rink, D. (2016). Varieties of shrinkage in European cities. European Urban and Regional Studies, 23(1), 86-102. doi:10.1177/0969776413481985

Haase, A., Herfert, G., Kabisch, S., \& Steinfuhrer, A. (2012). Reurbanizing Leipzig (Germany): Context Conditions and Residential Actors (2000-2007). European Planning Studies, 20(7), 1173-1196. doi:10.1080/09654313.2012.674349

Haggett, P. (2001). Geography. A Global Synthesis. Harlow: Prentice Hall.

Heidenreich, M. (1994). Central-European industry in transition to a market-economy. Zeitschrift Fur Soziologie, 23(1), 3-21.

Holesinska, A., \& Bobkova, M. (2015). Destination networks as a tool for minimizing the risk and improving the performance of a destination. Czech Journal of Tourism, 4(2), 91102. doi:https://doi.org/10.1515/cjot-2015-0006

Ianos, I. (2016). Causal Relationships Between Economic Dynamics and Migration: Romania as Case Study. Global Change and Human Mobility, 303-322. doi:10.1007/978-98110-0050-8_16 
Jigoria-Oprea, L., \& Popa, N. (2017). Industrial brownfields: An unsolved problem in postsocialist cities. A comparison between two mono industrial cities: Reia (Romania) and Panevo (Serbia). Urban Studies, 54(12), 2719-2738. doi:10.1177/0042098016655057

Kahrik, A., Leetmaa, K., \& Tammaru, T. (2012). Residential decision-making and satisfaction among new suburbanites in the Tallinn urban region, Estonia. Cities, 29(1), 49-58. doi:10.1016/j.cities.2011.07.005

Kim, E. J., \& Miller, P. (2017). Residents' perception of local brownfields in rail corridor area in the City of Roanoke: the effect of people's preconception and health concerns factors. Journal of Environmental Planning and Management, 60(5), 862-882. doi:10.1080/09640568.2016.1182898

Kim, H. R., \& Jang, Y. (2017). Lessons from good and bad practices in retail-led urban regeneration projects in the Republic of Korea. Cities, 61, 36-47. doi:10.1016/j.cities.2016.11.004

Klapka, P., Erlebach, M., Kral, O., Lehnert, M., \& Micka, T. (2013). The footfall of shopping centres in Olomouc (Czech Republic): An application of the gravity model. Moravian Geographical Reports, 21(3), 12-26.

Krejci, T., Dostal, I., Havlicek, M., \& Martinat, S. (2016). Exploring the hidden potential of sugar beet industry brownfields (case study of the Czech Republic). Transportation Research Part D-Transport and Environment, 46, 284-297. doi:10.1016/j.trd.2016.04.006

Krzysztofik, R., Kantor-Pietraga, I., Runge, A., \& Sporna, T. (2017). Is the suburbanisation stage always important in the transformation of large urban agglomerations? The case of the Katowice conurbation. Geographia Polonica, 90(2), 71-85. doi:10.7163/GPol.0082

Krzysztofik, R., Kantor-Pietraga, I., \& Sporna, T. (2013). A dynamic approach to the typology of functional derelict areas (Sosnowiec, Poland). Moravian Geographical Reports, 21(2), 20-35.

Krzysztofik, R., Tkocz, M., Sporna, T., \& Kantor-Pietraga, I. (2016). Some dilemmas of postindustrialism in a region of traditional industry: The case of the Katowice conurbation, Poland. Moravian Geographical Reports, 24(1), 42-54. doi:10.1515/mgr-2016-0004

Kubes, J. (2015). Analysis of regulation of residential suburbanisation in hinterland of postsocialist 'one hundred thousands' city of Ceske Budejovice. Bulletin of GeographySocio-Economic Series, 27(27), 109-131. doi:10.1515/bog-2015-0008

Kunc, J., Frantal, B., Tonev, P., \& Szczyrba, Z. (2012). Spatial patterns of daily and non-daily commutting for retail shopping: The case of the Brno city, Czech Republic. Moravian Geographical Reports, 20(4), 39-54.

Kunc, J., Krizan, F., Bilkova, K., Barlik, P., \& Maryas, J. (2016). Are there differences in the attractiveness of shopping centres? Experiences from the Czech and Slovak Republics. Moravian Geographical Reports, 24(1), 27-41. doi:10.1515/mgr-2016-0003

Kunc, J., Martinat, S., Tonev, P., \& Frantal, B. (2014). Destiny of urban brownfields: Spatial patterns and perceived censequences of post-socialistic deindustrialization. Transylvanian Review of Administrative Sciences(41E), 109-128.

Kunc, J., Navratil, J., Tonev, P., Frantal, B., Klusacek, P., Martinat, S., . . Cernik, J. (2014). Perception of urban renewal: Reflexions and coherences of socio-spatial patterns (Brno, Czech Republic). Geographia Technica, 9(1), 66-77.

Lafortezza, R., Corry, R. C., Sanesi, G., \& Brown, R. D. (2008). Visual preference and ecological assessments for designed alternative brownfield rehabilitations. Journal of Environmental Management, 89(3), 257-269. doi:10.1016/j.jenvman.2007.01.063

Legendre, P., \& Legendre, L. (2012). Numerical Ecology. Amsterdam: Elsevier. 
Lengyel, I., Vas, Z., Kano, I. S., \& Lengyel, B. (2017). Spatial differences of reindustrialization in a post-socialist economy: manufacturing in the Hungarian counties. European Planning Studies, 25(8), 1416-1434. doi:10.1080/09654313.2017.1319467

Leps, J., \& Smilauer, P. (2003). Multivariate Analysis of Ecological Data Using CANOCO. Cambridge: Cambridge University Press.

Longo, A., \& Campbell, D. (2017). The Determinants of Brownfields Redevelopment in England. Environmental \& Resource Economics, 67(2), 261-283. doi:10.1007/s10640015-9985-y

Lorber, L. (2014). Holistic approach to revitalised old industrial areas. 3rd International Geography Symposium, Geomed2013, 120, 326-334. doi:10.1016/j.sbspro.2014.02.110

Loures, L., Panagopoulos, T., \& Burley, J. B. (2016). Assessing user preferences on postindustrial redevelopment. Environment and Planning B-Planning \& Design, 43(5), 871-892. doi:10.1177/0265813515599981

Lusticky, M., \& Musil, M. (2016). Towards a Theory of Stakeholders' Perception of Tourism Impacts. Czech Journal of Tourism, 5(2), 93-110.

Maliene, V., Wignall, L., \& Malys, N. (2012). Brownfield regeneration: Waterfront site developments in Liverpool and Cologne. Journal of Environmental Engineering and Landscape Management, 20(1), 5-16. doi:10.3846/16486897.2012.659030

Martinat, S., Cyronova, K., Dvorak, P., \& Klusacek, P. (2014). Brownfields in Karvina: Opportunity or Threat? 17th International Colloquium on Regional Sciences, 621-631. doi:10.5817/cz.muni.p210-6840-2014-80

Martinat, S., Dvorak, P., Frantal, B., Klusacek, P., Kunc, J., Navratil, J., . . Reed, M. (2016). Sustainable urban development in a city affected by heavy industry and mining? Case study of brownfields in Karvina, Czech Republic. Journal of Cleaner Production, 118, 78-87. doi:10.1016/j.jclepro.2016.01.029

Maryas, J., Kunc, J., Tonev, P., \& Szczyrba, Z. (2014). Shopping and services related travel in the hinterland of Brno: Changes from the socialist period to the present. Moravian Geographical Reports, 22(3), 18-28. doi:10.2478/mgr-2014-0015

Molnar, E. (2016). Global production networks and regional development: A case study of the Hungarian footwear industry. DETUROPE - The Central European Journal of Regional Development and Tourism, 8(2), 48-57.

Mulkova, M., Popelka, P., \& Popelkova, R. (2016). Black Land: The Mining Landscape 25 of the Ostrava-Karvina Region. Landscapes and Landforms of the Czech Republic, 319332. doi:10.1007/978-3-319-27537-6 25

Nekolova, J., Hajek, O., \& Novosak, J. (2016). The location of economic activities in a postcommunist city: Twenty years of landuse change in the Ostravametropolitan area (Czech Republic). Transformations in Business \& Economics, 15(3C), 335-351.

Novotny, L., Csachova, S., Kulla, M., Nestorova-Dicka, J., \& Pregi, L. (2016). Development trajectories of small towns in East Slovakia. European Countryside, 8(4), 373-394. doi:10.1515/euco-2016-0026

Nuga, M., Metspalu, P., Org, A., \& Leetmaa, K. (2015). Planning post-summurbia: From spontaneous pragmatism to collaborative planning? Moravian Geographical Reports, 23(4), 36-46. doi:10.1515/mgr-2015-0023

Osman, R., Frantal, B., Klusacek, P., Kunc, J., \& Martinat, S. (2015). Factors affecting brownfield regeneration in post-socialist space: The case of the Czech Republic. Land Use Policy, 48, 309-316. doi:10.1016/j.landusepol.2015.06.003 
Otsuka, N., Dixon, T., \& Abe, H. (2013). Stock measurement and regeneration policy approaches to 'hardcore' brownfield sites: England and Japan compared. Land Use Policy, 33, 36-41. doi:10.1016/j.landusepol.2012.12.002

Ourednicek, M., Pospisilova, L., Spackova, P., Kopecka, Z., \& Novak, J. (2016). The velvet and mild Socio-spatial differentiation in Prague after transition. Socio-Economic Segregation in European Capital Cities: East Meets West, 89, 261-286.

Pizzol, L., Zabeo, A., Klusacek, P., Giubilato, E., Critto, A., Frantal, B., . . Bartke, S. (2016). Timbre Brownfield Prioritization Tool to support effective brownfield regeneration. Journal of Environmental Management, 166, 178-192. doi:10.1016/j.jenvman.2015.09.030

Quinn, G. P., \& Keough, M. J. (2002). Experimental design and data analysis for biologists. Cambridge: Cambridge University Press.

Rall, E. L., \& Haase, D. (2011). Creative intervention in a dynamic city: A sustainability assessment of an interim use strategy for brownfields in Leipzig, Germany. Landscape and Urban Planning, 100(3), 189-201. doi:10.1016/j.landurbplan.2010.12.004

Rink, D., \& Arndt, T. (2016). Investigating perception of green structure configuration for afforestation in urban brownfield development by visual methods-A case study in Leipzig, Germany. Urban Forestry \& Urban Greening, 15, 65-74. doi:10.1016/j.ufug.2015.11.010

Rizzo, E., Pesce, M., Pizzol, L., Alexandrescu, F. M., Giubilato, E., Critto, A., . . . Bartke, S. (2015). Brownfield regeneration in Europe: Identifying stakeholder perceptions, concerns, attitudes and information needs. Land Use Policy, 48, 437-453. doi:10.1016/j.landusepol.2015.06.012

Robinson, G. M. (1998). Methods and techniques in human geography. New York: J. Wiley. Rogatka, K., Chodkowska-Miszczuk, J., Bieganska, J., Sroda-Murawska, S., \& GrzelakKostulska, E. (2016). The role of public administration in shaping urban space in Poland. 19th International Colloquium on Regional Sciences, 605-612. doi:10.5817/cz.muni.p210-8273-2016-77

Schwarz, P. M., Depken, C. A., Hanning, A., \& Peterson, K. (2009). Comparing contaminated property redevelopment for mandatory and Voluntary Cleanup Programs in California. Journal of Environmental Management, 90(12), 3730-3735. doi:10.1016/j.jenvman.2009.02.018

Simis, M., Awang, A., \& Arifin, K. (2016). From Ex-landfill to Public Park: Impact on local community's quality of life and living environment. Asean-Turkey Asli Qol2015: Aicqol2015, 222, 763-771. doi:10.1016/j.sbspro.2016.05.157

Stasakova, G., \& Kulla, M. (2016). Sights of industrial heritage and their importance for developing tourism in Slovakia. Geographia Cassoviensis, 10(2), 159-174.

Szczepanska, A. (2016). Urbanization processes related to the development of residential functions in gminas adjacent to the city of Olsztyn. Bulletin of Geography-SocioEconomic Series, 33(33), 131-143. doi:10.1515/bog-2016-0030

Szczyrba, Z., \& Fiedor, D. (2014). Development of large-scale retail in Olomouc and shopping behaviour research. 17th International Colloquium on Regional Sciences, 740-748. doi:10.5817/cz.muni.p210-6840-2014-96

ter Braak, C. J. F., \& Smilauer, P. (2012). Canoco reference manual and users guide: Software for ordination (version 5.0). Ithaca: Microcomputer Power.

Tureckova, K., Skrabal, J., Benda, V., \& Martinat, S. (2016). Re-use of brownfields in Karvina: The challenge for local urban development. Vision 2020: Innovation Management, Development Sustainability, and Competitive Economic Growth, 2016, Vols I - Vii, 2436-2447. 
van Duijn, M., Rouwendal, J., \& Boersema, R. (2016). Redevelopment of industrial heritage: Insights into external effects on house prices. Regional Science and Urban Economics, 57, 91-107. doi:10.1016/j.regsciurbeco.2016.02.001

Van Kempen, R., \& Murie, A. (2009). The new divided city: Changing patterns in European cities. Tijdschrift Voor Economische En Sociale Geografie, 100(4), 377-398.

Wernerova, M. (2008). Perception of attractiveness and image of regional cities in Czechia on the example of university students in Ceske Budejovice and Usti nad Labem. Geografie, 113(1), 20-33. 